\title{
PENGARUH PEMBIAYAAN MUDHARABAH DAN MUSYARAKAH TERHADAP LIKUIDTAS INDUSTRI BANK SYARIAH DI INDONESIA 1)
}

\author{
Aulia Ramadhani \\ Mahasiswa Program Studi Ekonomi Islam-Fakultas Ekonomi dan Bisnis-Universitas Airlangga \\ Email: aulia_ramadhani08@ymail.com
}

Imron Mawardi

Departemen Ekonomi Syariah-Fakultas Ekonomi dan Bisnis-Universitas Airlangga

Email: ronmawardi@gmail.com

\begin{abstract}
:
This research aimed to know the influence of financing based on profit sharing against Islamic Banking Industry liquidity in Indonesia from January 2008 through June 2014. This research used the quantitative approach method. The analysis technique used was multiple linear regression and the equation was $Y=0,58+0,016$ (PMUD) - 0,056 (PMUS)

Based on the result of t-test, mudharabah financing and musyarakah financing partially did not influence significantly to liquidity with t test result consecutively 0,765 for mudharabah financing and 0,621 for musyarakah financing. The result of simultaneous test showed that mudharabah financing and musyarakah had significant effect to Islamic banking industry liquidity with siginificant value 0,000. And based on determination test result, the value of $R$ Square is 0,593 or $59,3 \%$ that showed the ability of mudharabah financing and musyarakah financing in explaining liquidity of $59,3 \%$ and the remaining $40,7 \%$ was explained by other variables outside the model.
\end{abstract}

Keywords: Mudharabah Financing, Musyarakah Financing, Liquidity, Cash Ratio, Islamic Banking Industry

\section{PENDAHULUAN}

\section{LATAR BELAKANG}

Krisis ekonomi diawali dengan gejolak moneter di negara-negara tetangga, sehingga nilai tukar rupiah melanda Indonesia (1997-1999) tingginya angka presentase kredit macet di satu sisi (aktiva), dan bunga deposito di sisi lain (pasiva) telah menimbulkan negative spread, dan satu-persatu bank di Indonesia dilikuidasi. Pada saat bank mengalami kebangkrutan masih ada satu bank yang bertahan yaitu Bank Muamalat, dengan menggunakan sistem bagi hasil. Kecenderungan masyarakat menggunakan sistem bunga lebih bertujuan untuk mengoptimalkan pemenuhan kepentingan pribadi, sehingga dinilai kurang mempertimbangkan dampak sosial yang ditimbulkan. Dalam panadangan islam bunga adalah riba. Seperti pada surat Ali Imron ayat 130

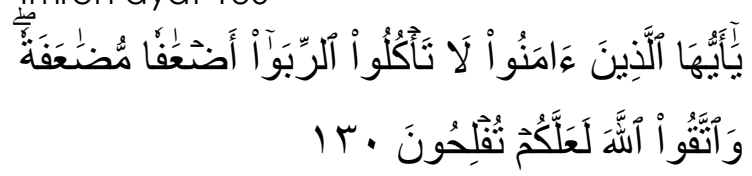

Yā ayyuhāl lażina ā manū la ta'kulūr ribā ad\{'a fam mud\{a 'fahtan wattaqülla ha la' allakum tuflihūn

Artinya: "Hai orang-orang yang beriman, janganlah kamu memakan Riba dengan berlipat ganda dan bertakwalah kamu kepada Allah supaya kamu mendapat keberuntungan."

Bank syariah adalah bank yang mekanisme kerjanya tanpa menggunakan sistem bunga, dengan

Jurnal ini merupakan bagian dari Skripsi yang ditulis oleh (Aulia Ramadhani; 041114171), yang diuji pada 4 Mei 2015. 
demikian bagi hasil merupakan mekanisme yang dominan di bank syariah. Bagi hasil merupakan ciri khusus yang membedakan antara bank syariah dan bank konvensional. Pembiayaan mudharabah dan pembiayaan musyarakah adalah pembiayaan dengan sistem bagi hasil.

Pembiayaan mudharabah adalah akad antara dua atau lebih pihak dimana satu pihak berperan sebagai pemilik modal (shahibul maal) dan mempercayakan sejumlah modlanya untuk dikelola oleh pihak kedua, yakni si pelaksana usaha (mudharib) dengan tujuan untuk mendapatkan keuntungan (Karim, 2004:204-205). Pembiayaan musyarakah adalah kerjasama antara dua pihak atau lebih untuk suatu usaha tertentu di mana masing-masing pihak memberikan kontribusi sana dengan keuntungan dan risiko akan ditanggung bersama sesuai dengan kesepakatan (Sudarsono, 2008:74).

Likuiditas merupakan rasio yang menggambarkan kemampuan perusahaan dalam memenuhi kewajiban (utang) jangka pendek (Kasmir, 2013:129). Berdasarkan UU No 10 Tahun 1998 tentang perbankan pasal 29 menerangkan bahwa bank wajib memelihara tingkat kesehatan bank sesuai dengan ketentuan kecukupan modal, kualitas aset, kualitas manajemen, likuiditas, rentabilitas, solvabilitas dan aspek lain yang berhubungan dengan usaha bank, dan bank wajib melakukan kegiatan usaha sesuai dengan prinsip kehati-hatian.

Sifat dari pembiayaan mudharabah dan musyarakah adalah natural uncertainty contract, yaitu suatu jenis kontrak transaksi dalam bisnis yang tidak memiliki kepastian atas keuntungan dan pendapatan, baik dari segi jumlah maupun waktu penyerahannya. Hal ini disebabkan karena kondisi ini terkait oleh kondisi di masa yang akan datang yang tidak dapat ditentukan atau dipastikan. Akibatnya, ketidakpastian pada asset lancar di bank syariah. Taswan (2010:245) menyatakan bahwa semakin besar dana mengendap di kas semakin likuid bank tersebut. Sebaliknya bila didominasi aset pada aktiva jangka panjang, maka pendapatan bank akan tinggi namun likuiditasnya rendah. Oleh karena itu perlu diteliti seberapa besar "pengaruh pembiyaan berbasis bagi hasil terhadap likuiditas industri Bank Syariah di Indonesia".

\section{RUMUSAN MASALAH}

Berdasarkan uraian latar belakang di atas, maka rumusan masalah yang dapat diajukan pada penelitian ini adalah:

1. Apakah pembiayaan mudharabah dan musyarakah berpengaruh secara parsial terhadap likuiditas industri Bank Syariah di Indonesia?

2. Apakah pembiayaan mudharabah dan musyarakah berpengaruh secara simultan terhadap likuiditas industri Bank Syariah di Indonesia? 


\section{TUJUAN PENELITIAN}

Berdasarkan uraian latar belakang dan rumusan masalah diatas, maka tujuan penelitian ini adalah:

1. Untuk mengetahui pengaruh secara parsial pembiayaan mudharabah dan musyarakah terhadap likuiditas industri Bank Syariah di Indonesia.

2. Untuk mengetahui pengaruh secara simultan pembiayaan mudharabah dan musyarakah terhadap likuiditas industri Bank Syariah di Indonesia.

\section{LANDASAN PUSTAKA}

\section{BANK SYARIAH}

Pengertian bank syariah adalah lembaga keuangan yang tata cara beroperasinya dalam penghimpunan dana maupun dalam rangka penyaluran dana, memberikan dan mengenakan imbalan didasarkan pada tata cara bermuamalat secara islami atau prinsip syariah, yakni mengacu kepada ketentuan-ketentuan Al-Qur'an dan Hadist atau dengan kata lain bank syariah adalah lembaga kevangan yang usaha pokoknya memberikan pembiayaan dan jasa-jasa lainnya dalam lalu lintas pembayaran dan peredaran uang yang pengoperasiannya disesuaikan dengan prinsip syariat islam.

\section{PEMBIAYAAN MUDHARABAH}

Menurut Antonio (2005:83) AlMudharabah adalah akad kerjasama usaha antara dua pihak dimana pihak pertama (Shahibul Maal) menyediakan seluruh (100\%) modal, sedangkan pihak lainnya menjadi pengelola. Keuntungan usaha secara mudharabah dibagi menurut kesepakatan yang dituangkan dalam kontrak, sedangkan apabila rugi ditanggung oleh pemilik modal selama kerugian itu bukan akibat kelalaian si pengelola, si pengelola harus bertanggung jawab atas kerugian tersebut. Kesediaan pemilik dana untuk menanggung risiko apabila terjadi kerugian menjadi dasar untuk mendapat bagian dari keuntungan.

\section{PEMBIAYAAN MUSYARAKAH}

Menurut Antonio (2005:90), al musyarakah adalah akad kerja sama antara dua pihak atau lebih untuk suatu tertentu dimana masing-masing pihak memberikan kontribusi dana dengan kesepakatan bahwa keuntungan dan resiko akan ditanggung bersama sesuai dengan kesepakatan. Akad Syirkah diperbolehkan menurut Ulama'Fiqih, berdasarkan Al-quran dan Al-hadits. Dalam Al-qur'an Allah SWT Berfirman dalam QS. Shaad: 24

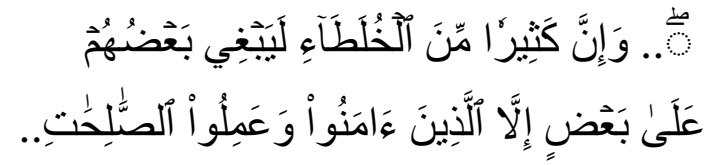

Wa-inna kas|i>ran minalkhulat\{a>-i layabgi> ba'd\{uhum 'ala> ba'din illallaz |i>na amanu> wa' amilu>-ssalhati Artinya: "... memang banyak diantara orang-orang yang bersekutu itu berbuat zalim kepada yang lain, kecuali orangorang yang beriman dan mengerjakan kerbajikan...."

\section{LIKUIDITAS}

Kasmir (2013:128) mengatakan bahwa ketidakmampuan perusahaan membayar 
kewajibannya terutama hutang jangka pendek (yang sudah jatuh tempo) disebabkan oleh berbagai faktor. Pertama, bisa dikarenakan memang perusahaan sedang tidak memiliki dana sama sekali. Atau kedua, bisa mungkin saja perusahaan tidak memiliki dana (tidak cukup) secara tunai sehingga harus mengunggu dalam waktu tertentu, untuk mencairkan aktiva lainnya seperti menagih piutang, menjual surat-surat berharga, atau menjual sediaan atau aktiva lainnya. Greuning dan labal (2011:143-146) menjelaskan kebutuhan likuiditas biasanya ditentukan oleh pembentukan jangka waktu yang terdiri dari arus kas masuk dan arus kas keluar yang diharapkan selama jangka waktu yang telah ditentukan. Perbedaan antara arus kas masuk dan keluar dalam setiap periode (yaitu, kelebihan atau kekurangan dana) memberikan titik awal untuk mengukur kelebihan atau kekurangan likuiditas bank di masa depan pada waktu tertentu.

\section{CASH RATIO}

Kasmir (2103:224) mengatakan bahwa cash ratio merupakan rasio yang digunakan untuk mengukur kemampuan bank dalam melunasi kewajiban yang harus segera dibayar dengan harta likuid yang dimiliki bank tersebut. Menurut Darmawi (2012:61) ukuran likuiditas yang mencerminkan konsep persediaan mengaitkan aset likuid terhadap total deposit atau total aset.

\section{HUBUNGAN PEMBIAYAAN BAGI HASIL TERHADAP LIKUIDITAS}

Muhammad (2005:358) menernagkan bahwa "Risiko pembiayaan muncul jika bank tidak bisa memperoleh kembali cicilan pokok dan/atau bunga yang diberikannya atau investasi yang sedang dilakukannya. Penyebab utama terjadinya risiko pembiayaan adalah terlalu mudahnya bank memberikan pinjaman atau melakukan investasi karena terlalu dituntut untuk memanfaatkan kelebihan likuiditas, sehingga penilaian kredit kurang cermat dalam mengantisipasi berbagai kemungkinan risiko usaha yang dibiayainya".

Greuning dan labal (2011:143) menyatakan bahwa posisi likuiditas yang lebih tinggi biasanya diperlukan ketika sebagian besar potofolio kredit terdiri dari pinjaman jangka panjang yang besar. Kebutuhan likuiditas biasanya ditentukan oleh pembentukan jangka waktu yang terdiri dari arus kas masuk dan arus kas keluar yang diharapkan selama jangka waktu yang telah ditentukan. Permana (2008) tentang pengaruh tingkat risiko pembiayaan terhadap likuiditas bank syariah pada PT. BPRS Ishlahul Ummah, diketahui bahwa terdapat pengaruh yang besar antara tingkat risiko pembiyaan terhadap tingkat likuiditas yaitu sebesar $78 \%$, sedangkan $22 \%$ adalah merupakan pengaruh yang ditimbulkan oleh faktorfaktor lain atau variabel lain yang di luar 
tingkat risiko pembiayaan maupun tingkat likuiditas.

\section{HIPOTESIS}

1. Pembiayaan mudharabah dan musyarakah berpengaruh secara parsial terhadap likuiditas industri bank syariah di Indonesia.

2. Pembiayaan mudharabah dan musyarakah berpengaruh secara simultan terhadap likuiditas indsutri bank syariah di Indonesia.

\section{MODEL ANALISIS}

Model analisis yang digunakan untuk rumusan dalam penelitian ini adalah metode analisis linier berganda. Model analisis yang digunakan dapat di formulasikan sebagai berikut:

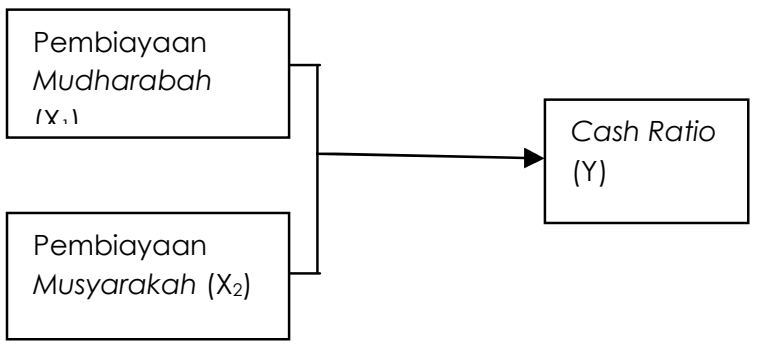

$$
\text { Gambar } 2.1
$$

Pengaruh Parsial dan Simultan

Persamaannya adalah :

$Y=a_{0}+\beta_{1} X_{1}+\beta_{2} X+e$

$Y=$ Cash Ratio

$\mathrm{X} 1$ = pembiayaan mudharabah

X2 = pembiyaan musyarakah

$a=$ intercept (konstanta)

$\beta=$ koefisien regresi masing masing variabel

e $=$ variabel pengganggu/error

\section{METODE PENELITIAN}

Pendekatan penelitian yang digunakan dalam penelitian ini adalah pendekatan kuantitatif.

\section{IDENTIFIKASI VARIABEL}

Variabel yang digunakan dalam penelitian ini dibeadakan menjadi 2 jenis, yaitu:

1. Variabel Bebas (Independent Variable)

$\mathrm{X} 1$ = Pembiayaan Mudharabah

X2 = Pembiayaan Musyarakah

2.Variabel Terikat (Dependent Variable)

$Y=$ Likuiditas Bank Umum Syariah dengan menggunakan cash ratio.

\section{JENIS DAN SUMBER DATA}

Jenis data yang digunakan dalam penelitian ini adalah data sekunder. Data sekunder adalah data yang dikumpulkan lembaga pengumpulan data dan di publikasikan kepada masyarakat yang membutuhkan data. Data sekunder dalam penelitian ini adalah data sekunder yang diambil dari statistik perbankan syariah yang diterbitkan otoritas jasa keuangan yang diambil pada periode Januari 2008-Juni 2014. Data pada penelitian ini termasuk dalam time series dengan skala nominal.

\section{POPULASI DAN SAMPEL}

Populasi dalam penelitian ini adalah industri perbankan syariah baik BUS maupun UUS di Indonesia. Menurut data yang dikumpulkan oleh OJK (Otoritas Jasa Keuangan)dan BI (Bank Indonesia) tercatat hingga tahun 2014 terdapat 11 Bank Umum Syariah dan 23 UUS yang ada di Indonesia. 
Metode pemilihan sampel yang digunakan pada penelitian ini adalah metode pemilihan sampel non acak (non probably sampling), Non probability sampling merupakan teknik pengambilan sampel yang tidak memberi peluang atau kesempatan sama bagi setiap unsur atau anggota populasi untuk dipilih menjadi sampel. Yaitu tipe sampel bertujuan (purposive sampling). Sampling purposive adalah teknik penentuan sampel dengan pertimbangan tertentu. Kriteria pemilihan sampel pada penelitian ini adalah industri perbankan syariah ada di Indonesia yang memiliki laporan keuangan dipublikasikan secara lengkap dari tahun 2008 hingaa 2014 dan merupakan gabungan dari BUS dan UUS periode Januari 2008-Juni 2014 sehingga sampel dalam penelitian ini berjumlah 78 sampel.

\section{DEFINISI OPERASIONAL}

Definisi operasional variabel-variabel yang digunakan dalam penelitian ini adalah:

1.Pembiayaan mudaharabah (X1) adalah pembiayaan yang disalurkan oleh bank kepada nasabah dengan menggunakan akad mudharabah. Data pembiayaan bagi hasil dengan akad mudharabah dihitung dari total rupiah pembiayaan mudharabah dibagi dengan total pembiayaan yang didapatkan nilai desimal pada periode Januari 2008 hingga Juni 2014.

2.Pembiayaan musyarakah (X2) adalah pembiayaan yang disalurkan oleh bank kepada nasabah dengan menggunakan akad musyarakah. Data pembiayaan bagi hasil dengan akad musyarakah dihitung dari total rupiah pembiayaan musyarakah dibagi dengan total pembiayaan yang didapatkan nilai desimal pada periode Januari 2008 hingga Juni 2014.

3.Likuiditas perbankan syariah dengan menggunakan Cash Ratio. Cash Ratio yang digunakan dalam penelitian ini diperoleh dari rumus (3.1) dengan menggunakan satuan persentase dengan periode Januari 2008 hingga Juni 2014 yang tercatat pada neraca gabungan BUS dan UUS. Rumus Cash Ratio adalah:

$$
\text { Cash Ratio }=\frac{\text { Liquid Assets }}{\text { Short Term Borrow }} \times 100 \%
$$

\section{TEKNIK ANALISIS}

Teknik analisis yang digunakan adalah regresi linier berganda.

\section{HASIL DAN PEMBAHASAN \\ Uji Normalitas}

Uji normalitas dapat ditempuh dengan menggunakan uji kolmogorov-smirnov test. Tujuannya adalah untuk mengetahui apakah data yang digunakan dalam suatu penelitian terdistribusi secara normal atau tidak. Metode kolmogorov-smirnov ini untuk yang tidak normal. Sehingga jika hasilnya signifikan atau $<0,05$ maka diambil kesimpulan bahwa data terdistribusi secara normal.

Uji autokorelasi yang menggunakan metode lag untuk penyembuhan metode tersebut menghasilkan tabulasi baru untuk pemrosesan sehingga dengan tabulasi tersebut semua uji yang ada dalam penelitian ini pun harus menyesuaikan 
dengan tabulasi tersebut serta memunculkan hasil yang baru untuk semua uji statistik termasuk pada uji normalitas, dan hasil yang digunakan adalah hasil setelah metode lag. Berikut hasil uji normalitas setelah di-lag yang disajikan melalui Tabel 4.5 di bawah ini

Tabel 1.

Uji Normalitas

One-Sample Kolmogorov-Smirnov Test

One-Sample Kolmogorov-Smirnov Test

\begin{tabular}{|ll|r|}
\hline & & $\begin{array}{r}\text { Unstandardized } \\
\text { Residual }\end{array}$ \\
\hline $\mathrm{N}$ & 77 \\
Normal & Mean & .0000000 \\
Parameters $^{\mathrm{a}, \mathrm{b}}$ & Std. & .01802482 \\
& Deviation & \\
Most Extreme & Absolute & .105 \\
Differences & Positive & .105 \\
& Negative & -.050 \\
Kolmogorov-Smirnov Z & .918 \\
Asymp. Sig. (2-tailed) & .368 \\
\hline
\end{tabular}

Sumber: Hasil Uji SPSS 19

Tabel 1 menunjukkan hasil uji One sampe Kolmogorov-smirnov di atas dieproleh nilai Asymp. Sig.(2-tailed) sebesar 0,260. Karena nilai 0,260 lebih besar dari 0,05, maka dapat disimpilkan bahwa terdistribusi normal.

\section{Uji Multikolinearitas}

Cara umum yang digunakan oleh peneliti untuk mendeteksi ada tidaknya problem multikolinearitas pada model regresi adalah dengan melihat nilai tolerance dan VIF (Variance Inflation Factor), jika nilai VIF lebih dari 10 dan tolerance value nya kurang dari 0,1 maka terjadi multikolinearitas yang berarti terdapat hubungan antara variabel independen penelitian tersebut. uji autokorelasi yang menggunakan metode lag untuk peyembuhannya metode tersebut menghasilkan tabulasi yang baru semua uji yang ada dalam penelitian ini pun harus menyesuaikan dengan tabulasi tersebut serta memunculkan hasil yang baru untuk semua uji statistik termasuk pada uji multikolinearitas, dan hasil yang digunakan adalah hasil setelah metode lag. Berikut hasil uji multikolinearitas setelah di-lag yang disajikan melalui Tabel 2 dibawah ini

Tabel 2.

Uji Multikolinearitas

\begin{tabular}{|c|c|c|c|c|}
\hline $\begin{array}{c}\text { Variabel } \\
\text { Indepede } \\
n\end{array}$ & $\begin{array}{c}\text { Nila } \\
\text { i } \\
\text { VIF }\end{array}$ & $\begin{array}{c}\text { Nilai } \\
\text { Toleran } \\
\text { ce }\end{array}$ & $\begin{array}{l}\text { Interpret } \\
\text { asi Hasil }\end{array}$ & Keterangan \\
\hline $\begin{array}{l}\text { Pembiay } \\
\text { aan } \\
\text { Mudhara } \\
\text { bah }\end{array}$ & $\begin{array}{l}1,7 \\
30\end{array}$ & 0,574 & $\begin{array}{c}\text { Nilai } \\
\text { toleranc } \\
e>0,10 \\
\text { Nilai VIF } \\
<10\end{array}$ & $\begin{array}{c}\text { Tidak terjadi } \\
\text { multikolinea } \\
\text { ritas }\end{array}$ \\
\hline $\begin{array}{c}\text { Pembiay } \\
\text { aan } \\
\text { Musyarak } \\
\text { ah }\end{array}$ & $\begin{array}{l}1,7 \\
11\end{array}$ & 0,585 & $\begin{array}{c}\text { Nilai } \\
\text { toleranc } \\
e>0,10 \\
\text { Nilai VIF } \\
<10\end{array}$ & $\begin{array}{c}\text { Tidak terjadi } \\
\text { multikolinea } \\
\text { ritas }\end{array}$ \\
\hline
\end{tabular}

Sumber : Lampiran 4 , hasil uji SPSS 19 (data telah diolah)

Berdasarkan Tabel 2, nilai tolerance dari masing-masing variabel nilainya lebih dari 0,10 dan VIF nya kurang dari 10 sehingga dpaat dikatakan bahwa variabel independen yang ada dalam penelitian ini sudah terbebas dan sembuh dari multikolinearitas, sehingga kedua variabel tersebut dapat digunakan untuk menjelaskan variabel dependen dalam penelitian ini.

\section{Uji Heteroskedastisitas}


Uji Heteroskedastisitas dapat ditempun dengan melihat grafik scatterplot. Model regresi yang kita inginkan adalah yang homokedastisitas atau tidak terjadi problem heteroskedastisitas. Homokedastisitas pada model regresi yang diteliti maka dapat disimpulkan bahwa variabel dependen benar-benar hanya dijelaskan oleh variabel independenya atau dapat dikatakan tidak terjadi hubungan anatra variabel pengganggu dengan variabel independenya. Cara mendeteksi ada atau tidaknya heteroskedastisitas dapat dilakukan dengan cara melihat pola tertentu pada grafik scatterplot. Jika tidak ada pola, serta titik-titik menyebar diatas dan dibawah angka 0 pada sumbu $Y$, maka tidak terjadi heteroskedastisitas.

Uji autokorelasi menggunakan metode lag untuk penyembuhan metode tersbut menghasilkan tabulasi baru untuk pemrosesan sehingga dengan tabulasi yang baru semua uji yang ada dalam penelitian ini pun harus menyesuaikan dengan tabulasi tersebut serta memunculkan hasil yang baru untuk semua uji statistik termasuk pada uji heteroskedastisitas, dan hasil yang digunakan adalah hasil setelah metode lag uji heteroskedastisitas. Berikut hasil uji heteroskedastistas yang disajikan melalui Gambar 1

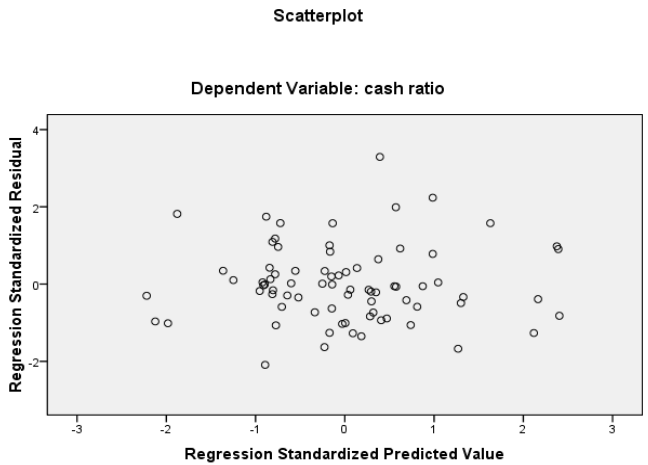

Gambar 1.

Uji Heteroskedastisitas

Sumber: Hasil uji SPSS 19 (data telah diolah)

\section{Uji Autokorelasi}

Uji autokorelasi ditempuh dengan melakukan uji statistik Durbin-Watson. Untuk uji Durbin-Watson akan dibandingkan hasil DW ststistik dan DW tabel. Digunakan untuk menguji adanya korelasi antara varian error atau penganggu pada periode tertentu dengan periode sebelumnya.

Tabel 3.

Uji Autokorelasi Durbin Watson

\begin{tabular}{|c|c|c|c|}
\hline Nilai & Nilai & Interpretasi & Keterangan \\
Durbin- & DU & Hasil & \\
Watson & dan & & \\
& Nilai & & \\
& $\mathrm{DL}$ & & \\
\hline 0,485 & $\mathrm{dL}=$ & $\mathrm{DW}<\mathrm{DU}$ & Terjadi \\
& 1.580 & & Autokorelasi \\
& $\mathrm{dU}=$ & & \\
& 1.685 & & \\
\hline
\end{tabular}

Sumber: Lampiran 3 , hasil uji SPSS 19 (data telah diolah)

Tabel 3 diatas menunjukkan bahwa nilai Durbin-Watson sebesar 0,507 dan jika dibandingkan dengan dU dna dL dengan $\mathrm{a}=5 \%$ didapat $\mathrm{dU}=1,580$ dan $\mathrm{dL}=1,685$, sehingga tidak memenuhi syarat bebas 
autokorelasi sehingga dapat disimpulkan bahwa variabel dalam penelitian ini mengalami masalah autokorelasi. Terdapat beberapa cara untuk menyembuhkan masalah autokorelasi, salah satunya dengan cara lag. Cara pemrosesan lag yaitu dengan melakukan lag pada variabel $Y$, setelah kita melakukan metode lag berarti kita mendapatkan tabulasi data yang baru berupa lagY. Dan dengan metode lag penelitian ini akan terbebas dari masalah autokolinear. Berikut Tabel hasil yang telah disembuhkan dengan metode lag dengan SPSS.

Tabel 4.

Uji Autokorelasi

Setelah Penyembuhan dengan Metode Lag

\begin{tabular}{|c|c|c|c|}
\hline $\begin{array}{c}\text { Nilai } \\
\text { Durbin- } \\
\text { Watson }\end{array}$ & $\begin{array}{c}\text { Nilai } \\
\text { dU } \\
\text { dan } \\
\text { nilai } \\
\text { dL }\end{array}$ & $\begin{array}{c}\text { Interpretasi } \\
\text { Hasil }\end{array}$ & Keterangan \\
\hline 1,696 & $\begin{array}{c}\mathrm{dL}= \\
1,550 \\
\mathrm{dU}= \\
1,711\end{array}$ & $\begin{array}{c}\mathrm{dU}<\mathrm{DW}<<- \\
\mathrm{dU}\end{array}$ & $\begin{array}{l}\text { Tidak terjadi } \\
\text { Autokorelasi }\end{array}$ \\
\hline
\end{tabular}

Sumber: Lampiran 4, hasil uji SPSS 19 (data telah diolah)

Tabel 4 diatas, nilai Durbin-Watson sebesar 1,696 dan lebih besar dari nilai dU nya tetapi lebih kecil dari nilai 4-dU nya sehingga memenuhi prasyarar dan dapat dikatakan bahwa variabel yang ada dalam penelitian ini sudah terbebas dari masalah autokolinear, sehingga variabelvariabel tersebut dapat digunakan untuk mejelaskan variabel terikat dalam penelitian ini.
Berdasarkan pola yang tersebar dalam Gambar 4.4, dapat dilihat bawa titik- titik menyebar. Titik-titik data tersebut menyebar tidak beraturan diatas dana dibawah sumbu 0 pada sumbu $Y$. Sehingga dapat disimpulkan bahwa dalam data tersbut tidak terjadi heteroskedastisitas.

\section{Koefisien Determinasi (R-Squares)}

Koefisien determinasi menunjukkan seberapa besar kemampuan variabel independen dalam menerangkan variasi variabel dependen. Bila semakin tingggi nilai R2 suatu regresi tersebut semakin baik. Yang berarti bahwa variabel independen memberikan hampir semua informasi yang dibutuhkan untuk memprediksi variasi variabel dependen.

Berdasarkan uji sebelumnya yaitu uji autokorelasi yang menggunakan metode lag untuk penyembuhan metode tersebut menghasilkan tabulasi baru untuk pemrosesan sehingga dengan tabulasi tersebut semua uji yang ada dalam penelitian ini pun harus menyesuaikan dengan tabulasi tersebut serta memunculkan hasil yang baru untuk semua uji statistik termasuk pada uji normalitas, dan hasil yang digunakan adalah hasil setelah metode lag. Berikut hasil dari koefisien determinasi berganda setelah di-lag yang disajikan melalui Tabel 5 di bawah ini 
Tabel 5.

Hasil Koefisien Dterminasi Berganda

Model Summary

\begin{tabular}{|c|c|c|c|c|c|}
\hline $\begin{array}{l}\text { Mo } \\
\text { del }\end{array}$ & $\mathrm{R}$ & $\begin{array}{c}\mathrm{R} \\
\text { Squar } \\
\mathrm{e}\end{array}$ & $\begin{array}{c}\text { Adjuste } \\
d R \\
\text { Square }\end{array}$ & $\begin{array}{c}\text { Std. } \\
\text { Error of } \\
\text { the } \\
\text { Estimat } \\
\mathrm{e}\end{array}$ & $\begin{array}{l}\text { Durbin- } \\
\text { Watson }\end{array}$ \\
\hline & $.770^{\mathrm{a}}$ & .593 & .577 & .01839 & 1.696 \\
\hline
\end{tabular}

a. Predictors: (Constant), LagY, pembiayaan musyarakah, pembiayaan mudharabah

b. Dependent Variable: cash ratio

Sumber: Lampiran 4, Hasil SPSS 19 (diolah kembali)

Tabel 5 ditunjukkan nilai hasil $R$ Square yaitu sebesar 0,593 atau sebesar 59,3\%, artinya variabel independen yaitu pembiayaan mudharabah dan pembiayaan musyarakah dapat menjelaskan variabel dependen yaitu likuiditas industri bank syariah sebesar $59,3 \%$ sedangkan sisanya $40,7 \%$ dijelaskan oleh variabel-variabel lain di luar variabel yang digunakan dalam penelitian ini.

\section{Uji Regresi Linier Berganda}

Analisis regresi linear berganda merupakan model analisis untuk mengetahui pengaruh pembiayaan mudharabah dan pembiayaan musyarakah secara simultan terhadap likuiditas industri bank syariah di Indonesia. Di dalam hasil olahan regresi linier berganda terdapat persamaan yang menunjukkan model regresi penelitian ini. Berdasrkan uji sebelumnya yaitu uji autokorelasi yang menggunakan metode lag untuk penyembuhan metode tersebut menghasilkan tabulasi baru untuk pemrosesan sehingga dengan tabulasi yang baru semua uji yang ada dalam penelitian ini pun harua menyesuaikan dengan tabulasi tersebut serta memunculkan hasil yang baru untuk semua uji asumsi klasik termasuk pada uji linier regresi berganda, dan hasil yang digunakan adalah hasil setelah metode lag.

Tabel 6.

Uji Regresi Linier Berganda

\begin{tabular}{|l|l|l|}
\hline Variabel & $\begin{array}{l}\text { Koefisien } \\
\text { B }\end{array}$ & Keterangan \\
\hline Konstanta & 0,58 & Konstanta \\
\hline $\begin{array}{l}\text { Pembiayaan } \\
\text { mudharabah }\end{array}$ & 0,016 & $\begin{array}{l}\text { Bernilai } \\
\text { Positif }\end{array}$ \\
\hline $\begin{array}{l}\text { Pembiayaan } \\
\text { Musyarakah }\end{array}$ & $-0,056$ & $\begin{array}{l}\text { Bernilai } \\
\text { negatif }\end{array}$ \\
\hline
\end{tabular}

Sumber: Lampiran 4, Hasil SPSS 19 ( diolah kembali)

Tabel 6 diatas menunjukkan persamaan regresi linier berganda dapat diperoleh sebagai berikut:

Ylik $=0,58+0,016$ (PMUD) - 0,056 (PMUS)

Penjelasan dari persamaan tersebut adalah sebagai berikut:

a.Konstanta sebesar 0,58 menunjukkan apabila variabel pembiayaan mudharabah dan pembiayaan musyarakah besarnya nol, maka nilai likuiditas adalah sebesar 0,58.

b.Koefisien regresi pembiayaan mudharabah sebesar 0,016 memiliki arti jika variabel lain konstan maka, setiap kenaikan pembiayaan mudharabah sebesar satu satuan akan meningkatkan likuiditas sebesar 0,016 satuan. Begitu pula 
sebaliknya, setiap penurunan pembiaayan mudharabah sebesar satu satuan akan menurunkan likuiditas sebesar 0,016 satuan.

c.Koefisien regresi pembiayaan musyarakah sebesar -0,056 memiliki arti jika variabel lain konstan maka, setiap kenaikan pembiayaan musyarakah sebesar satu satuan akan menurunkan likuiditas sebesar 0,056. Begitu pula sebaliknya, setiap penurunan pembiayaan musyarakah sebesar satu satuan akan menaikkan likuiditas sebesar 0,056 satuan.

\section{Pengujian Hipotesis}

Berdasarkan latar belakang, rumusan masalah, tujuan penelitian dan landasan teori, berikut adalah hipotesis yang digunakan dalam penelitian ini :

$\mathrm{Hl}$ : pembiayaan mudharabah dan musyarakah berpengaruh secara simultan terhadap likuiditas bank syariah.

$\mathrm{H} 2,3$ : Pembiayaan mudharabah dan musyarakah berpengaruh secara parsial terhadap likuiditas bank syaria

\subsubsection{Uji Simultan (F-test)}

Uji F merupakan uji model secara keseluruhan/simultan. Uji $F$ digunakan untuk melihat pengaruh variabel bebas secara bersama-sama terhadap variabel terikat. Hipotesis dari uji F adalah sebagai berikut :

Nilai $F$ hitung statistik yang digunakan adalah $F$ hitung setelah metode lag karena menggunakan tabulasi baru dampak dari penyembuhan masalah uji autokolinear. Berikut hasil dari Tabel 7 yang menunjukkan hasil uji simultan.

Tabel 7.

Uji Simultan (f-test)

\begin{tabular}{|c|c|c|c|c|}
\hline $\begin{array}{c}\text { Probab } \\
\text { ility } \\
\text { Value }\end{array}$ & A & $\begin{array}{c}\text { Penguji } \\
\text { an } \\
\text { Hipotesi } \\
\text { s }\end{array}$ & $\begin{array}{c}\text { Inter } \\
\text { pret } \\
\text { asi }\end{array}$ & Keterangan \\
\hline 0,000 & $\begin{array}{c}0,0 \\
5\end{array}$ & $\begin{array}{c}0,000< \\
0,05\end{array}$ & $\begin{array}{c}\mathrm{H}_{0} \\
\text { ditol } \\
\text { ak }\end{array}$ & $\begin{array}{c}\text { H0 ditolak } \\
\text { sehingga } \\
\text { ariable } \\
\text { independen } \\
\text { secara } \\
\text { simultan } \\
\text { berpengaru } \\
\text { h signifikan } \\
\text { terhadap } \\
\text { ariable } \\
\text { dependen. }\end{array}$ \\
\hline
\end{tabular}

Sumber : Lampiran 4, hasil SPSS 19 (diolah kembali)

Hasil uji F pada Tabel 7 maka dapat dinyatakan bahwa $\mathrm{HO}$ ditolak karena nilai signifikansinya $<0,05$ sehingga dapat disimpulkan bahwa pembiayaan mudharabah dan pembiayaan musyarakah secara simultan berpengaruh signifikan terhadap likuiditas industri bank syariah di Indonesia pada $a=0,05$.

\section{H.Uji Parsial (t-test)}

Uji parsial dilakukan untuk melihat signifikansi pengaruh masing-masing variabel dalam menerangkan variasi variabel dependen. 
Tabel 8.

Uji Parsial (t-test)

\begin{tabular}{|c|c|c|c|c|c|c|}
\hline $\begin{array}{l}\text { Varia } \\
\text { bel } \\
\text { Bebas }\end{array}$ & $\mathrm{T}$ & $\begin{array}{l}\text { p- } \\
\text { val } \\
\text { ue }\end{array}$ & $A$ & $\begin{array}{l}\text { Pen } \\
\text { gujia } \\
n \\
\text { Hipo } \\
\text { tesis }\end{array}$ & $\begin{array}{l}\text { Inter } \\
\text { pret } \\
\text { asi }\end{array}$ & $\begin{array}{l}\text { Keter } \\
\text { ang } \\
\text { an }\end{array}$ \\
\hline $\begin{array}{l}\text { Mudh } \\
\text { araba } \\
h(X 1)\end{array}$ & $\begin{array}{r}0, \\
30 \\
0\end{array}$ & $\begin{array}{l}0 \\
7 \\
6 \\
5\end{array}$ & $\begin{array}{l}0 \\
5\end{array}$ & $\begin{array}{l}0,76 \\
5> \\
0,05\end{array}$ & $\begin{array}{l}\mathrm{H}_{0} \\
\text { diter } \\
\text { ima }\end{array}$ & $\begin{array}{l}\text { signif } \\
\text { ikan }\end{array}$ \\
\hline $\begin{array}{l}\text { Musy } \\
\text { araka } \\
\mathrm{h}(\mathrm{X} 2)\end{array}$ & $\begin{array}{r}- \\
0 \\
49 \\
6\end{array}$ & $\begin{array}{r}0 \\
6 \\
2 \\
1\end{array}$ & $\begin{array}{l}1 \\
0 \\
5\end{array}$ & $\begin{array}{l}0,62 \\
1 \\
>0,0 \\
5\end{array}$ & $\begin{array}{l}\mathrm{H}_{0} \\
\text { diter } \\
\text { ima }\end{array}$ & $\begin{array}{l}\text { Tidak } \\
\text { signif } \\
\text { ikan }\end{array}$ \\
\hline
\end{tabular}

Sumber: Lampiran 4, hasil SPSS 19 (diolah kembali)

Berdasarkan uji parsial (t-test) yang dapat dilihat pada Tabel 8 , nilai p-value variabel mudharabah >a. Sehingga variabel mudharabah tidak berpengaruh secara signifikan terhadap likuiditas bank syariah di Indonesia.

$\mathrm{HO}: \beta 2=0, \mathrm{HO}$ diterima (artinya variabel musyarakah secara parsial tidak berpengaruh signifikan terhadap likuiditas).

$\mathrm{Hl}: \beta 2 \neq 0, \mathrm{HO}$ ditolak (artinya variabel musyarakah secara parsial berpengaruh signifikan terhadap likuiditas).

Berdasarkan uji parsial t-test yang dapat dilihat pada Tabel 4.10, nilai $\dagger$ hitung variabel musyarakah sebesar -0,496 dan nilai $p$ value $>a$. Sehingga variabel musyarakah tidak berpengaruh secara signifikan terhadap likuiditas bank syariah di Indonesia

\section{PEMBAHASAN}

Berdasarkan hasil pengolahan data dapat dianalisa bahwa model yang terdapat masalah autokorelasi, hal tersebut dapat ditunjukkan dari nilai durbin-watson sebesar 0,485 dan nilai tersebut berada dibawah nilai dU tabel. Terdapat bebarapa cara untuk mengobati masalah tersebut. Peneliti lebih mengambil cara mengobati masalah tersebut dengan metode lag. Firdaus (2004:100) cara untuk menghilangkan pengaruh autokorelasi yang terdapat dalam model regresi adalah dengan memasukkan lag ke dalam variabel dependennya. Metode lag dilakukan dengan cara mentransform variabel $Y$ menjadi lag $Y$. Lalu menambahkanya pada variabel independen. Dampak dari metode tersebut mengahsilkan tabulasi baru untuk pemrosesan sehingga dengan tabulasi yang baru semua uji yang ada dalam penelitian ini pun harus menyesuaikan dengan tabulasi tersebut serta memunculkan hasil yang baru untuk semua uji statistik.

Pengaruh Pembiayaan Mudharabah dan Musyarakah Secara Simultan Terhadap Likuiditas Bank Syariah di Indonesia

Hasil dari penelitian ini menunjukkan bahwa pembiayaan mudharabah dan musyarakah secara bersama-sama berpengaruh signifikan terhadap likuiditas bank syariah di Indonesia $\mathrm{Hal}$ tersebut didukung dengan teori Taswan (2010:249) anticipated Income Theory dari lending. Teori ini secara prinsip bahwa bank memungkinkan lebih cocok (properly) untuk memberikan kredit jangka panjang dengan sekedul pembayaran kembali 
(angsuran dan bunga) yang telah ditentukan. Skedul pembayaran kembali/angsuran ini akan menyediakan sumber likuiditas untuk memenuhi kebutuhan likuiditas bank.

Pembiayaan mudharabah pada bank syariah untuk membiayai usaha yang pendapatannya sudah pasti dan marginnya sudah ditentukan di awal. Sebagai contoh bank syariah melakukan executing dengan BMT. Executing adalah bank memberikan pembiayaan kepada perusahaan mitra dimana kemudian perusahaan mitra meneruskan kepada nasabah sebagai end user, sehingga perusahaan mitra tercatat sebagau debitor bank sedangkan pembiayaan kepada end user tercatat sebagai eksposur pembiayaan mitra. Sedangkan pada pembiayaan musyarakah risiko yang dihadapi lebih tinggi karena pendapatan bersifat tidak pasti. Dari ketidakpastian pendapatan pada pembiayaan musyarakah ini akan mempengaruhi likuiditas bank syariah. Hal tersebut sesuai dengan hadits qudsi yang diriwayatkan oleh Abu Hurairah Radhiyallahu anhu bahwa Rasulullah Shallallahu a'laihi wa sallam bersabda:

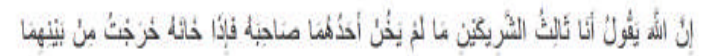

Innaallaha yaqu>lu innatalisussyari>kaini ma>lamyakhun ahaduhuma> s\}a>hinahu khanahu kharajtu baihima>

Sesungguhnya Allâh Azza wa Jalla berkata, "Aku adalah pihak ketiga (Yang
Maha Melindungi) bagi dua orang yang melakukan syirkah, selama salah seorang diantara mereka tidak berkhianat kepada mitranya. Apabila diantara mereka ada yang berkhianat, maka AkU akan keluar dari mereka (tidak melindungi)". Kaidah dari hadist tersebut jika dikaitkan dengan penelitian ini adalah pembiayaan musyarakah (syirkah) memiliki risiko yang lebih tinggi dengan banyaknya orang yang berkhianat dalam berserikat (syirkah).

Pembiayaan merupakan salah satu aktiva produktif, aktiva produktif adalah aktiva yang dimiliki bank yang digunakan untuk memperoleh pendapatan. Dari pendapatan yang diterima dari hasil pembiayaan ini akan mempengaruhi likuiditas bank itu sendiri. Ketika pendapatan pembiayaan bagi hasil mengalami kenaikan maka tingkat likuiditas bank akan mengalami kenaikan, ketika pendapatan pembiayaan bagi hasil ini rendah maka tingkat likuiditas bank juga akan rendah. Tetapi pengelolaan manajemen likuiditas harus dijalankan dengan baik. Jika pembiayaan yang tinggi akan meningkatkan laba bank itu sendiri, namun bank juga harus melakukan pengawasan agar pembiayaan yang diberikan tidak berlebihan. Namun, rasio likuiditasnya jika terlalu rendah juga berakibat tidak baik bagi bank itu, likuiditas rendah berarti pendapatan dari pembiayaan yang dilakukan sedikit. Jika pendapatan sedikit maka pertumbuhan bank itu akan 
semakin lamban. Hal ini bisa terjadi dikarenakan manajemen operasional bank yang kurang bagus dan manajemen likuiditas yang kurang agresif.

Hal tersebut di dukung oleh hasil penelitian dari Permana (2008) menjelaskan bahwa besar kecilnya risiko pembiayaan menunjukkan kemampuan bank dalam mengelola dananya. Timbulnya kredit bermasalah dapat diakibatkan oleh kurang cermatnya bank dalam melakukan penilaian terhadap penyaluran salah satunya dengan pembiayaan sehingga risiko tersebut berdampak pada menurunnya tingkat penghasilan bank serta mengakibatkan bank mengalami kesulitan likuiditas.

Hal-hal tersebut sesuai dengan penelitian yang dilakukan penulis bahwa pembiayaan mudharabah dan pembiayaan musyarakah secara simultan berpengaruh signifikan terhadap likuiditas bank syariah di Indonesia.

\section{Pengaruh Pembiayaan Mudharabah} Secara Parsial Terhadap Likuiditas Bank Syariah di Indonesia

Pengaruh pembiayaan mudharabah secara parsial terhadap likuiditas industri bank syariah didapat dilihat dari hasil uji $\dagger$ yang menyatakan bahwa pembiayaan mudharabah tidak berperngaruh signifikan secara parsial terhadap likuiditas bank syariah di Indonesia periode Januari 2008-Juni 2014. Berdasarkan uji parsial ttest yang telah dilakukan, hasilnya dari nilai siginifikansinya adalah 0,765, yang berarti lebih dari 0,05 maka kesimpulannya pembiayaan mudharabah tidak berpengaruh signifikan terhadap likuiditas bank syariah di Indonesia.

Menurut Antonio (2005:83) AlMudharabah adalah akad kerjasama usaha antara dua pihak dimana pihak pertama (Shahibul Maal) menyediakan seluruh (100\%) modal, sedangkan pihak lainnya menjadi pengelola. Keuntungan usaha secara mudharabah dibagi menurut kesepakatan yang dituangkan dalam kontrak, sedangkan apabila rugi ditanggung oleh pemilik modal selama kerugian itu bukan akibat kelalaian si pengelola, si pengelola harus bertanggung jawab atas kerugian tersebut. Dari teori diatas, bank memberikan kontribusinya $100 \%$ untuk dikelola oleh nasabah, sehingga dana yang dikeluarkan lebih besar daripada pendapatan yang diterima. Pendapatan bagi hasil yang diberikan pada pembiayaan mudharabah sifatnya tidak pasti, jika usaha yang dilakukan oleh nasabah itu berhasil maka pendapatan bagi hasil yang diterima oleh bank tinggi, namun jika usaha tersebut tidak menghasilkan keuntungan maka tidak ada keuntungan yang dibagihasilkan. Hal ini berarti pengeluaran dana untuk pembiayaan mudharabah kurang berpengaruh terhadap ketersedian vang kas untuk menjaga likuiditas bank.

Arifin (2005:123) mengatakan bahwa ketika bank mendanai pinjaman jangka panjang, maka ia juga menghadapi risiko likuiditas yang tinggi. Pembiayaan 
mudharabah merupakan pembiayaan dengan jangka panjang yang berarti bahwa mudharabah memiliki risiko likuiditas yang tinggi. Kesulitan likuiditas yang dialami oleh bank pada umumnya diakrenakan bank memiliki pembiayaan dalam jangka pendek dan menyalurkannya ke dalam pembiayaan dengan jangka waktu panjang. Ketidaksesuaian antara jangka waktu penghimpunan dana dari masyarakat dan jangka waktu penempatan dana tersebut menyulitkan bank memenuhi kewajiban-kewajiban kepada nasabah dan pihak lainnya. Selain itu, dapat saja terjadi penarikan dana dalam jumlah yang sangat besar oleh nasabah sehingga dapat juga berdampak terhadap kegiatan dan prospek usaha bank tersebut.

\section{Pengaruh Pembiayaan Musyarakah}

Secara Parsial Terhadap Likuiditas Bank Syariah di Indonesia

Pengaruh pembiayaan musyarakah secara parsial terdap likuiditas bank syariah dapat dilihat dari hasil uji hipotesis $†$ yang menyatakan bahwa pembiayaan musyarakah berpengaruh tidak signifikan secara parsial terhadap likuiditas bank syariah di Indonesia periode Januari 2008Juni 2014. Hal tersebut ditunjukkan dari nilai signifikansi nya sebesar 0,621 yang lebih besar dari 0,05, maka dapat ditarik kesimpulan bahwa pembiayaan musyarakah berpengaruh tidak signifikan terhadap likuiditas secara parsial.
Pembiayaan musyarakah termasuk dalam earning asset, atau yang sering disebut dengan aktiva produktif. Aktiva produktif merupakan aktiva yang dimiliki bank yang digunkan untuk memperoleh pendapatan. Jika dilihat dari data, pendapatan musyarakah jauh lebih banyak daripada pendapatan mudharabah. Antonio (2005:83) musyarakah adalah akad kerjasama antara dua pihak atau lebih untuk suatu usaha tertentu dimana masing-masing pihak memberikan kontribusi dana dengan kesepakatan bahwa keuntungan dan risiko akan ditanggung bersama sesuai dengan kesepakatan.

Mudharabah dan musyarakah merupakan perjanjian pembagian keuntungan dan kerugian serta menghadapi hilangnya modal walau dengan pengawasan yang memadai. Tingkat risiko relatif lebih tinggi dibandingkan pada investasi lain. Dan bank syariah harus sangat berhati-hati dalam mengevaluasi dan memilih proyek untuk mengurangi potensi kerugian (Greunning dan labal, 201 1:192).

Berdasarkan data dari statistik perbankan syariah bahwa yang mendominasi justru murabahah, hal ini ditunjukkan dari besarnya komposisi pembiayaan yang diberikan murabahah jauh lebih besar dari pembiayaan bagi hasil yaitu mudharabah dan musyarakah.

\section{SIMPULAN DAN SARAN}

\section{SIMPULAN}


Berdasarkan hasil analisis dan pembahasan pada bab sebelumnya, penulis mengambil kesimpulan sebagai berikut:

1. Pembiayaan mudharabah dan musyarakah secara simultan berpengaruh terhadap likuiditas bank umum syariah di Indonesia. Dengan persamaan regresi berganda: Ylik= 0,58 + 0,016 (PMUD) - 0,056 (PMUS)

2. Pembiayaan mudharabah secara parsial mempunyai pengaruh yang tidak signifikan terhadap likuiditas industri bank syariah di Indonesia. Dan pembiayaan musyarakah secara parsial memiliki perngaruh yang tidak signifikan terhdap likuiditas industri bank syariah di Indonesia.

\section{DAFTAR PUSTAKA}

Antonio, Muhammad Syafi'i. 2005. Bank Syari'ah Dari Teori Ke Praktek. Jakarta: Gema Insani Press

Darmawi, Herman. 2012. Manajemen Perbankan. Jakarta: Bumi Aksara

Djarwanto. 2004. Pokok-Pokok Analisis Laporan Kevangan. BPFE. Yogyakarta

Firdaus, Muhammad. 2004. Ekonometrika Suatu Pendekatan Aplikatif. Jakarta: Sinar Grafika Offset.

Greuning, Van dan Iqbal, 2011. Analisis Risiko Perbankan Syariah. Jakarta: Salemba Empat

Karim, Adiwarman, 2004. Bank Islam Analisis Fiqih dan Keuangan. Jakarta: PT Raja Grafindo Persada

Kasmir .2013. Analisis Laporan Keuangan. Jakarta: Salemba Empat.
Muhammad. 2005. Manajemen Dana Bank Syariah. Jakarta : Ekonisia

Muhammad. 2001. Tehnik Perhitungan Bagi Hasil di Bank Syariah, UII Press, Yogyakarta

Otoritas Jasa Keuangan. 2014. Statistik Perbankan Syariah Edisi Januari 2008 sampai Juni 2014. www.ojk.go.id

Permana, Agung. 2008. Pengaruh Tingkat Risiko Pembiayaan terhadap Likuiditas Bank Syariah pada PT. BPRS Ishlahul Ummah. Skripsi. Universitas Komputer Indonesia. Bandung.

Sudarsono, Heri. 2008. Bank dan Lembaga Keuangan Syariah.Yogyakarta : EKONISIA

Sugiyono. 2012. Metode Penelitian Kuantitatif Kualitatif dan R\&D. Bandung: Alfabeta

Taswan. 2010. Manajemen Perbankan I Konsep, Teknis \& Aplikasi). Yogyakarta: UPP STIM YKPN 